\title{
$\mathrm{SMC}$ の流動特性と成形欠陷 ${ }^{\dagger}$ 繊維配向の影響
}

$\begin{array}{lll}\text { 片 山 傳 生 } & \text { 稲 穂 敬 } \text { ** }^{* *} \text { 篠 原 正 浩*** } \\ \text { 早 川 雄 三*** 箱 谷 昌 宏*** } & \end{array}$

\section{Flow Characteristics and Forming Defects in SMC Relation between Fiber Orientation and Defects -}

\author{
by \\ Tsutao Katayama ${ }^{*}$, Takao InAho ${ }^{* *}$, Masahiro Shinohara $* *$, \\ Yuzo HaYaKaWA ${ }^{* * * *}$ and Masahiro HaKotani ${ }^{* * *}$
}

\begin{abstract}
Sheet Molding Compound (SMC) products such as one piece panel, have always stiffening ribs. In this product, some defects are observed. They are sink mark, weld lines, warpage and heat cracks. These defects are greatly influenced by the molding condition of SMC, especially material flow. In the design of the mold, the material flow is an important factor. But the material flow of SMC is complex and unsteady. So, CAD system of SMC is needed to design a molding die. Therefore, the present authors are constructing the data base to design the compression molding process of SMC.

In this paper, the flow characteristics and forming defects of SMC products were investigated. In flow characteristics, attention was paid to the branch of material flow around the rib part. To obtain the relation between flow characteristics and defects, the molding processes for T-shaped products were carried out by varying the charge pattern and the shape of the rib. Then the warpage was measured and the heat crack was observed. On the other hand, the data of fibre orientation was taken in the cross section of molding products.

Moreover, to construct CAD system of SMC, the thermal shrinkage in cooling down after the process was calculated by using the deformation model for the numerical analysis where SMC has the anisotropic homogeneity.

Key words : SMC, Stiffening ribs, Flow characteristics, Warpage, Heat cracks
\end{abstract}

\section{1 緒言}

複合材料の一種である SMC ( Sheet Molding Compound）成形品は一般に薄肉成形品の場合, 剛性向 上のためリブを伴う。しかし，リブを設けることにより リブ背面部表面にヒケと称するへこみ, 繊維の非貫通部 分であるウエルドライン，繊維の蛇行，成形品のそりお よびヒートクラックと称するき裂等の欠陥の発生がみら れる. ${ }^{1)} \mathrm{SMC}$ の成形欠陥は成形条件に大きく依存してお り，特に材料流動は欠陥にかなり影響を及ぼす。しかし， SMC の材料流動は複雑で非定常であり, また金型の幾 何学的形状により流動様相が大きく異なる。攵のため, 欠陥を抑制するような金型を設計するためには試行錯誤 せざるをえず，金型設計の効率化には $\mathrm{CAD}$ システムが 必要となる。しかし, リブを有する 3 次元形状成形品の SMC 流動を完全にシミュレートするのは非常に困難と なる.

そこで，本研究ではデータベースをもとにした CAD システムの構築を考え, 成形シミュレートの簡略化を試
みた。まず，本研究では欠陥の主な原因となるリブ部の 材料の流入分岐に着目し，これを考虑した流動解析を行 う必要があると考光, 流入分岐を増分流入比という形で 表現し，これをデータベース化した。本論文では流動解 析は行っていないが, このデータベースにより今後は流 動解析を 3 次元で行う必要がなくなり, 2 次元平面方向 でのリブを仮想的に設けた解析が可能にするものである.

さらに, 本研究では欠陥の中でもそりとヒートクラッ クに注目し成形欠陥発生の臨界条件の把握を試みた。本 研究では，簡便な成形欠陥の発生予測を行うため欠陥の 主要因を繊維配向に着目し，その他の欠陥要因である繊 維含有率, ガラス繊維分布等の要因を除いた。ここで, 繊維配向は成形時の流動に大きく依存するため, まず, 材料流動を検討した。さらに，CAD システムとして SMC を均質異方性とし有限要素法を用いて熱収縮解析 および残留応力解析を行い, 実際の欠陉発生状況と比較 検討した。

\section{2 実 験 方 法}

\footnotetext{
$\dagger$ 原稿受理 平成 8 年12月10日 Received Dec. 10,1996

* 正 会 員 同志社大学工学部機械系学科 ₹ $610-03$ 京田辺市多々羅都谷, Dept. of Mech. Eng., Doshisha Univ., Tatara, kyotanabe, 610-03

** 同志社大学大学院 T610-03 京田辺市多々羅都谷, Graduate Student, Doshisha Univ., Tatara, kyotanabe, 610-03

$* * *$ 正会員 舞鶴工業高等専門学校 † 625 舞鶴市字白屋, Maizuru National College of Tech., Shiraya, Maizuru, 625

$* * * *$ 正 会 員 武田薬品工業(株)化学品カンパニー化成品研究所 テ 532 大阪市淀川区十三本町, Res Labs., Chemical Company Division, Takeda Chemical Indust. Ltd., Yodogawa-ku, Osaka, 532
} 


\section{$2 \cdot 1$ 成形金型}

成形に用いた金型の概略図をFig. 1に示す.

金型の中心部分にはリブを設けてあり , リブ幅 $B$ を 2 , $5,10,20,40,60,80 \mathrm{~mm}$ とリブ高さ $H$ を $10,20,30$, $40 \mathrm{~mm}$ と変化させることが可能である。

\section{$2 \cdot 2$ 成形材料}

本実験では，ガラス繊維長 1 inch（約 $25.4 \mathrm{~mm}$ ），ガラ 又含有率 $28.0 \mathrm{wt} \%$ ，厚さ約 $2 \mathrm{~mm}$ の SMC 材を用い，積層 枚数は, 成形品板厚 $t$ が約 $5 \mathrm{~mm}$ になるように決定した. また，本研究では各層の動きを明確にするため色のみが 異なる 2 種類の SMC を交互に積層した。本研究ではチ ヤージ率は 100\%，60\%，30\% で成形を行った。ここで, チャージ率とは，金型面積に対する材料面積の割合を表 しており，材料長さのみを変化させ材料の幅は $240 \mathrm{~mm}$ 一定とした。成形時のチャージ位置は Fig. 2 に示すとお りである。

\section{$2 \cdot 3$ 成形条件}

成形は FRP 圧縮成形用 $150 \mathrm{t}$ プレスを用いて上型の型 締速度 $0.15 \mathrm{~mm} / \mathrm{s}$, 型内圧力は $10 \mathrm{MPa}$ で成形を行った。 金型温度は上型扎よび下型共に $140^{\circ} \mathrm{C}$ に設定した。ま た，成形品は充分硬化させた後脱型し室温下にて自然冷 却を行った。

\section{SMC の流動特性}

\section{$3 \cdot 1$ 実験方法}

本研究では SMC の流動特性の中でも特に，材料がリ ブを越えて流動する際の流入分岐について着目した。実 験方法は成形時においてショートショットを行いショー

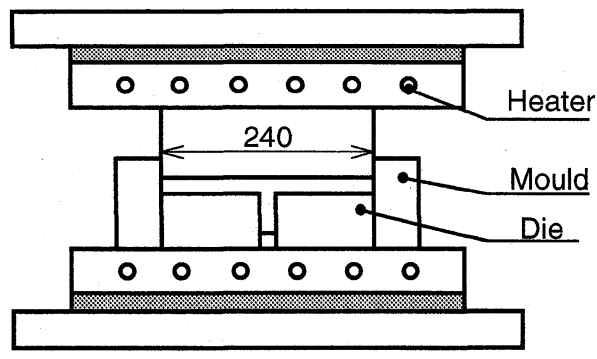

Fig. 1. Schematic diagram of matched die.

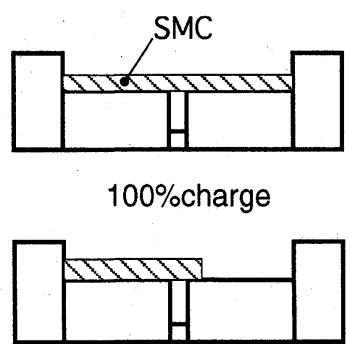

$60 \%$ charge

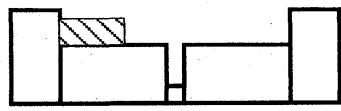

$30 \%$ charge
トショットされた成形品をもとにリブ部と平板部の増分 流入比を算出した. ${ }^{2}$ 本研究ではショートショットはリブ 高さ $H=20 \mathrm{~mm}$ で行った．また，リブ部と平板部の流入 比は非定常に変化すると考元られるためリブの充填段階 を流入初期 I, 中期 II，後期 III と 3 段階に分けた。段 階の区分は材料充填がリブ体積の $1 / 3$ までを I 段階, $2 / 3$ までをII段階，完全充填までを四段階とした。ま た，流入比は材料が全て平板部に流動すると $100 \%$ ，全 てリブ部に流動すると $0 \%$ となるように分岐流量より計 算した．金型の幾何学的形状を表すパラメータとしては,

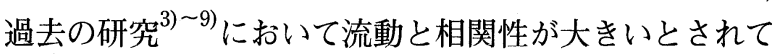
いるリブ幅 $B$ とリブ部に材料が到達した際の材料厚さ $t_{s}$ の比 $B / t_{s}$ を用いた。

\section{$3 \cdot 2$ 流動特性}

流入比と $B / t_{s}$ の結果を Fig. 3 に示す．これより全体的 にチャージ率が $60 \%$ ，30\% 共に右下がりとなり，またあ る値以上で流入比が 0 となる傾向を示している．30\% 天 ャージの場合，I段階に执いては $B / t_{s}$ が小さいと $100 \%$ 近い值，つまり平板方向に流動する傾向が見られる。し かし $B / t_{s}$ が 1.0 より大きくなると流量比が 0 になってい ることがわかる．II段階ではＩ段階に比べてリブ部充填 量が大きいため $B / t_{s}$ が 1.0 から 2.0 付近でも約 $50 \%$ の值 となり平板部に流動が始まっていることがわかる．四段 階に打いてはほぼ $B / t_{s}$ 全域に扔いて平板流動が始まるこ とがわかる。

次にチャージ率が $60 \%$ の場合について考察する。 I 段 階では $30 \%$ チャージに比べ $B / t_{s}$ が 1.0 より小さい值で流 量比が 0 になっている。これは，60\%チャージではイニシ ヤルチャージの時点で材料がリブ上にあるため上型が接 触するとすぐリブ部に流動が始まり，平板部には全く流 動しないものと考えられる。しかし，リブ部の材料充填 量が大きくなるにつれて $30 \%$ チャージとほぼ同様の流入 比になることがわかった.

本研究条件では, ごの場合も最終段階で平板部が充填 している。この点で $100 \%$ チャージと大きく異なった.

\section{$4 \cdot 1$ そりの測定方法}

そりの量 $W$ を Fig. 4 に示すように定義した。そりはリ ブに垂直な方向 3 箇所において測定を行い，その 3 箇所 の平均值をその成形品のそりの量とした．また，成形品 のそりは Fig. 4 のように山状となる場合と，逆に谷状と なる場合がある。よって，そりの值は谷状のそりを正， 山状のそりを負と定義する。

\section{$4 \cdot 2$ リブ形状がそりに与える影響}

本研究では, 成形欠陥と材料流動の相関性を考慮し， リブ幅 $B$ 打よびリブ高さ $H$ と成形品板厚 $t$ との比 $B / t$, $H / t$ を形状特性として用いた。まず，欠陥が発生しやす いと思われる $100 \%$ チャージの $B / t$ とそりの量の関係を Fig. 5 に，また，成形品の断面写真を Fig. 6 に示す. Fig. 5 より, $B / t$ の值が 1.0 付近でそりの量が最大となっ ている。これは Fig. 6 でリブ肩部付近での繊維配向の迂

Fig. 2. Charge pattern. 


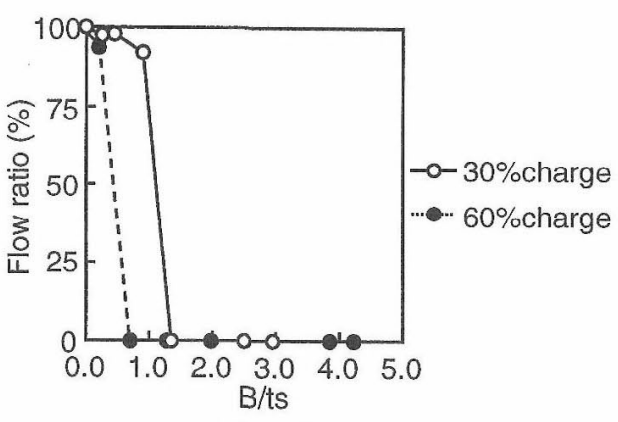

a) Stage I

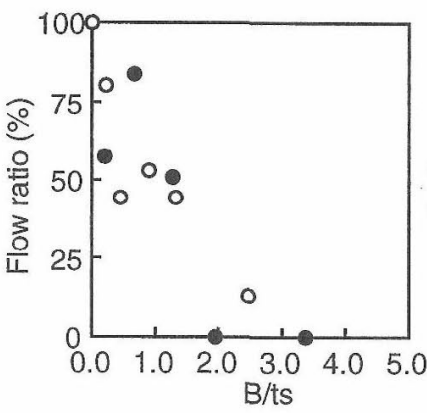

b) Stage II

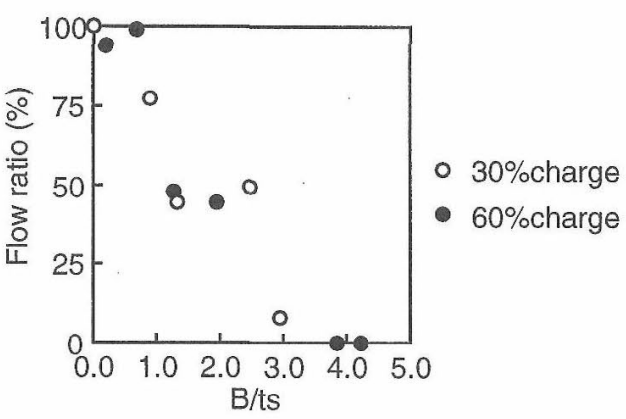

c) Stage III

Fig. 3. Relationship between flow ratio and $B / t_{s}$.

回がみられ，その繊維配向の向きに平板部が傾いたため と考えられる。また $B / t$ が大きくなると，过回がリブ内 部に入り込むため，そりは減少すると考えられる。

次に $H / t$ とそりの量 $W$ との関係を Fig. 7 に示す。リブ 高さを変化させてもリブ肩付近の繊維配向（迂回）に違 いが観られないため，そりの量にも大きな差珙が生じな かったと考えられる。

\section{4・3 チャージ率がそりに与える影響}

チャージ率を変化させたときのそりの結果を Fig.8 に 示す. $100 \%$ チャージでは $4 \cdot 2$ 節で検討したように，そ りはリブ肩部付近に抢ける纎維配向の迂回が原因と考え られる。一方，60\%，30\% チャージではそりの值は 100\% チャージにくらべ大きく減少し，ほぼ０に近い值を示し ていることがわかる．Fig.6 を観るとそりの原因と考光 られるリブ肩部付近での迂回が 60\%，30\% チャージでは ほぼ見られない。これがそりの大きな低減につながった ものと考えられる。

成形時の流動状況では，まず $100 \%$ チャージの場合， 材料は未充填空間がない平板部には流動せずリブ部のみ に流動する。SMC 材は面内にガラス繊維を有するため

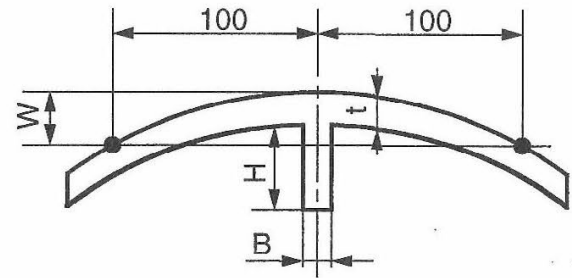

Fig. 4. Definition of warpage quantity.

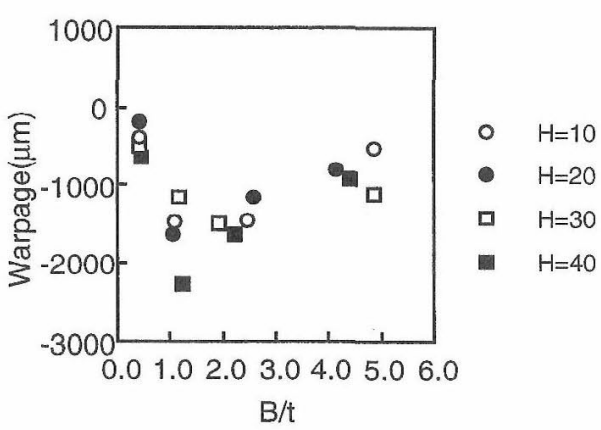

Fig. 5 . Relationship between warpage and $B / t$.

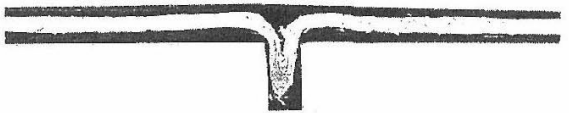

a) $100 \%$ charge

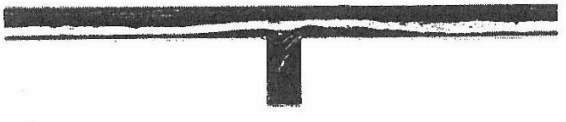

b) $60 \%$ charge

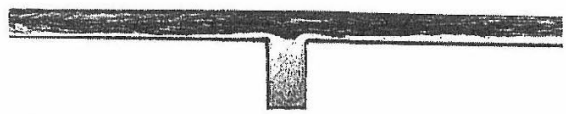

c) $30 \%$ charge

Fig. 6. Cross section of products $(B=5 \mathrm{~mm}, H=$ $10 \mathrm{~mm}$ ).

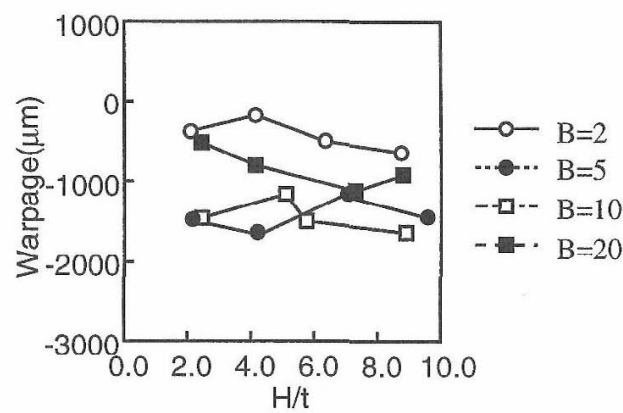

Fig. 7. Relationship between warpage and $H / t$.

曲げ岡性が大きく，迁回は流動時に材料が無理にリブ部 に流入しようとして生じたと考光られる。それに対して， 60\%，30\% チャージの場合は流動はリブ部だけではなく 平板部にも流動する。そのため，リブ部に流入する際， 無理な変形力がかかりにくく迁回などが生じにくかった と考えられる。 


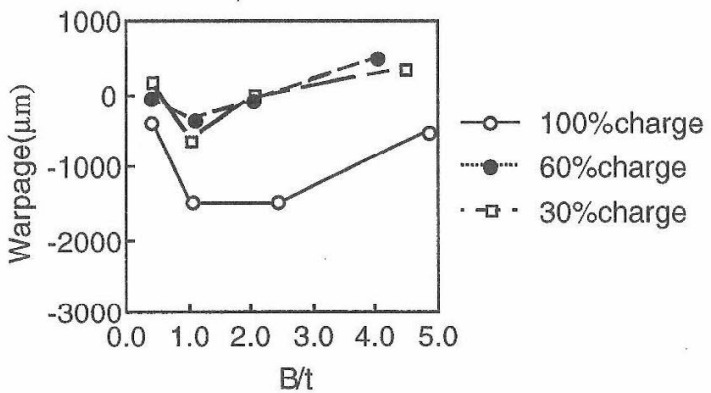

Fig. 8. Relationship between warpage and $B / t(H=$ $10 \mathrm{~mm})$.

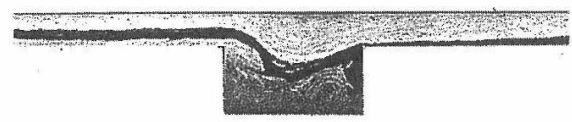

a) $B=20 \mathrm{~mm}, \mathrm{H}=10 \mathrm{~mm}$

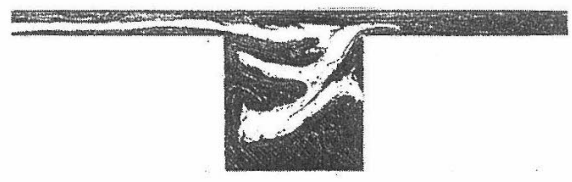

b) $\mathrm{B}=20 \mathrm{~mm}, \mathrm{H}=20 \mathrm{~mm}$

Fig. 9. Cross section of products (30\%charge).

しかし， $60 \% ， 30 \%$ チャージに扔いても $B / t$ が 1.0 付近 において若干負のそりが現れている。 Fig. 3 では $B / t_{s}$ が 小さいと流入比が $100 \%$ 近い值を示している。つまり， 流動初期に平板部に大きく流入し，穴の後りブに充填し たと考光られる。爷のため，リブへの流動が $100 \%$ チヤ 一ジに似た流動となり，負のそりが現れたと考光られる。

また， $60 \% ， 30 \%$ チャージの $B / t$ が 4.0 以上になると正 のそりが生じている。これは Fig.9 に示すようにリブ付 根付近の繊維配向が V 字状になっているため, 成形品 に谷状のそり（正のそり）が生じたと考觉られる。

よって，チャージ率を小さくし平面流動を起こすよう に成形すればそりを無くせると言われるが，本研究の結 果, $B / t=1.0$ 付近ではそりの量は少ないが発生すること がわかった。

\section{$4 \cdot 4$ 熱収縮解析 $^{10)}$}

本節では $\mathrm{CAD}$ システムの 1 つである号り解析について 檢討する。只り解析は, 成形後金型から取り出された成 形品が室温まで冷却されることを想定して熱收縮解析を 行った。解析に打ける要素分割を Fig. 10 に, SMC 成形 品より求めた材料定数を Table I に示守。解析は SMC を均質異方性体として扱い，要素ごとに成形品より測定 した繊維配向を入力し有限要素法を用いて弾性解析を行 った。

解析結果を Fig. 11 に示す. 解析結果を実験結果と比 較すると解析結果は実駼值と良く一致している。そりは 成形品内部の繊維配向に大きく影響されて扎り, 只り解 析には成形流動で生じる繊維配向を把握する必要がある ことがわかる。

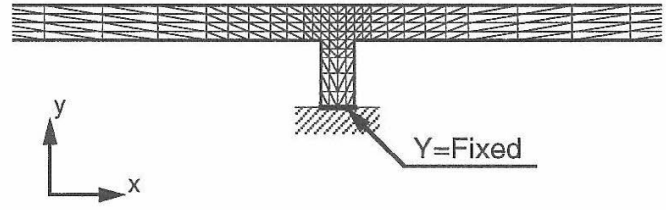

Fig. 10. Finite element model for thermal shrinkage analysis.

Table I. Material constant of SMC used in this analysis.

\begin{tabular}{c|rc}
\hline Longitudinal modulus & EL & $12.0 \mathrm{GPa}$ \\
\hline Transverse modulus & ET & $7.2 \mathrm{GPa}$ \\
\hline Shear modulus & Es & $6.9 \mathrm{GPa}$ \\
\hline Poisson's ratio & \multicolumn{2}{|c}{0.29} \\
\hline Thermal expansion & $\alpha \mathrm{L}$ & $2.3 \times 10^{-5} 1 / \mathrm{K}$ \\
coefficient & $\alpha \mathrm{T}$ & $7.5 \times 10^{-5} 1 / \mathrm{K}$ \\
\hline Moulding temperature & \multicolumn{2}{|c}{$140^{\circ} \mathrm{C}$} \\
\hline Room temperature & \multicolumn{2}{|c}{$25^{\circ} \mathrm{C}$} \\
\hline
\end{tabular}

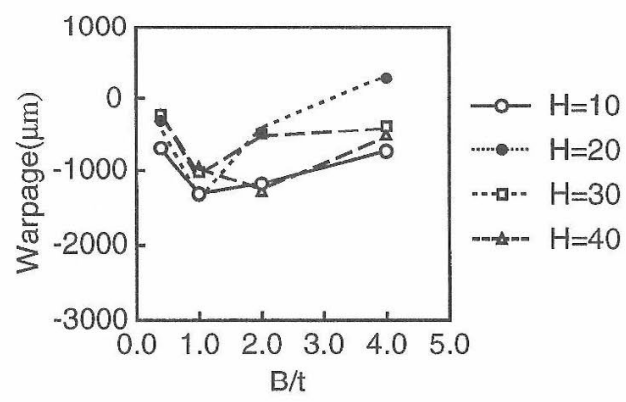

Fig. 11. Relationship between warpage and $B / t$ (Analysis).

$$
5 \text { ヒートクラックの発生 }
$$

SMC 成形品の剛性向上ために設けられたリブ付近に 沶いて，熱収縮によるき裂が生じることがある。このヒ 一トクラックが発生すると, 成形品の強度低下を引き起 こしたり，外観を損なう。本節ではヒートクラックの発 生要因について检討卞る。

\section{$5 \cdot 1$ ヒートクラックの発生要因}

ヒートクラックはリブ背面部括よびリブ側面部に発生 が観られた。まず, 100\% チャージのヒートクラックの発 生状況を Fig. 12 に示す。これより,リブ背面部では $B / t$ が大きくなるほど，また， $H / t$ が小さくなるほど， ヒートクラックが発生している。 また，リブ側面部では, $B / t$ が 3.0 上り大きくなるとリブ側面部にヒートクラッ クが発生している。次に，チャージ率を $60 \%, 30 \%$ で成 形を行うとリブ背面部，リブ側面部ともにヒートクラッ クの発生は観られなかった。

ヒートクラックの発生要因を检討するため, リブ内部 の繊維配向の写真を Fig. 13 に示す。これより，100\% チ ャージではリブ内部で繊維がかなり蛇行しているのがわ かる。これに対し，60\%，30\% チャージでは激しい繊維 の蛇行は見られない。材料流動を考枀ると Fig. 3 より材 料がリブ流入時に同時に平板部にも流動しており，材料 の座屈が起こりにくくなり，蛇行がほとんど生じなかっ 


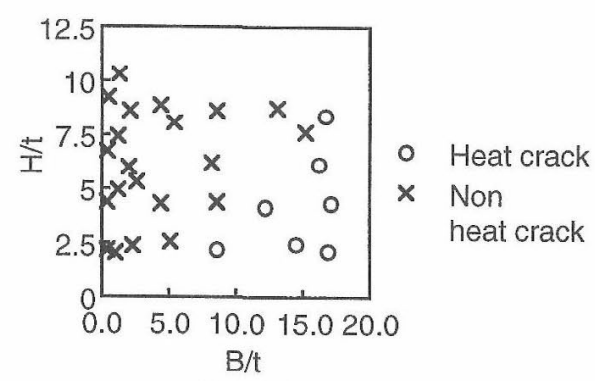

a) Back face

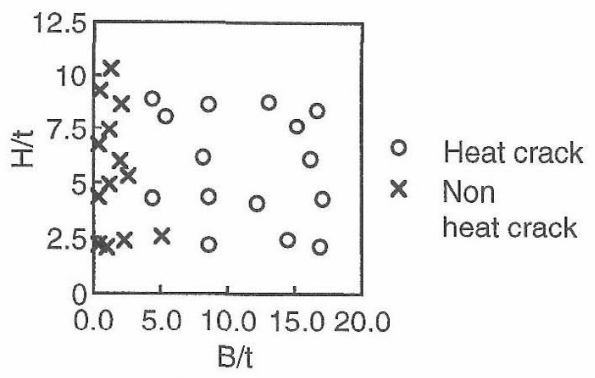

b) Side face

Fig. 12. Presence of heat crack (100\%charge).

たと考えられる。そのため，ヒートクラックが発生しな かったと思われる。

\section{$5 \cdot 2$ 残留応力解析}

ヒートクラックに詨する $\mathrm{CAD}$ システム構築のため残 留応力解析を行った。 この解析も $4 \cdot 4$ 節の只り解析と 同様であるが残留応力解析では SMC が金型内にあるの を想定し，境界条件で金型に接している節点が金型を押 すような反力を持つと変位を拘束するような非線形増分 法を用いて解析を行った。残留心力解析の結果である相 当応力の分布を Fig. 14 に示す。こ扎り応力集中の位置 とヒートクラックの位置が一致していることがわかる。

また，チャージ率を変化させてもリブ内部に生じる残 留応力の分布に大きな違いは見られなかった。このこと より，ヒートクラックはウエルドラインやレジンリッヂな じの強度の低い部分と熱収縮によって生じる残留応力の 集巾部分が重なると発生すると考学られる。

また, Fig. 15 は相当応力の最大値の結果を表してい る. 相当応力の最大值は $B / t$ が 3.0 付近で急激に増加し ている。この結果は Fig. 12 のヒートクラックの発生状 況と良く一致している。

以上のように解析結果より, ヒートクラックの発生傾 向は把握できたが，発生するか否かを解析により判定す るには至らなかった。纎維配向をもっと小さいスケール で把握したり，あるいはレジンリッチなどの不均質性を 考慮する必要があると思わ机る。

\section{6 結言}

本研究では $\mathrm{SMC}$ 圧縮成形に打ける $\mathrm{CAD}$ システム構築 のため，欠楩であるそりとヒートクラックに着目し，ま ず，繊維配向に大きく影響する材料流動について検討し た。また，成形欠陥の CAD システムである熱収縮解析， 残留応力解析を行い，以下のような結言を得た。

（1） 欠陥に大きく影響を及ぼすリブ部付近の流動状態

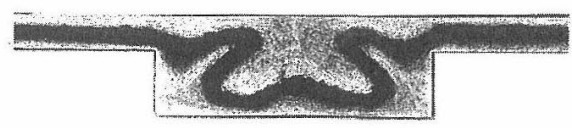

a) $100 \%$ charge

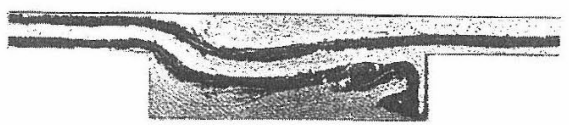

b) $60 \%$ charge

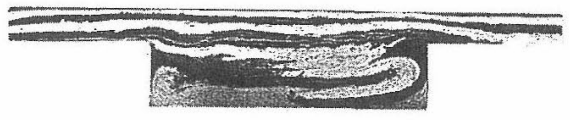

c) $30 \%$ charge

Fig. 13. Cross section of products $(B=40 \mathrm{~mm}, H=$ $10 \mathrm{~mm})$.

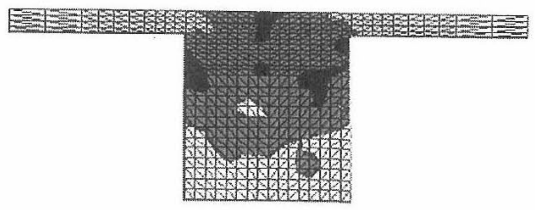

a) $B=40 \mathrm{~mm}, H=40 \mathrm{~mm}$

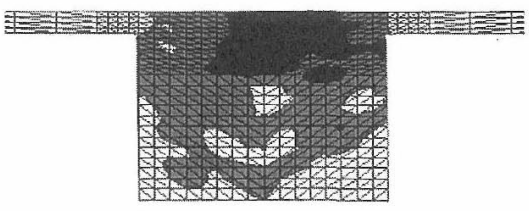

b) $\mathrm{B}=60 \mathrm{~mm}, \mathrm{H}=4.0 \mathrm{~mm}$

Fig. 14. Distribution of equivalent stress (100\%charge).

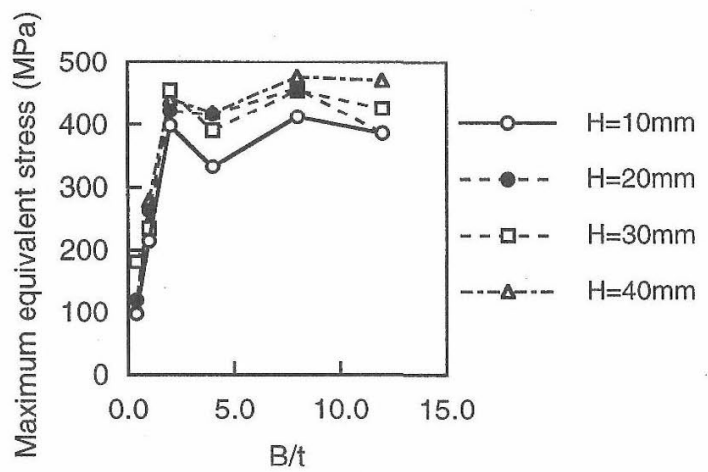

Fig. 15. Relationship between maximum equivalent stress and $B / t$.

は，平板部とリブ部への流動分岐をリブ幅と流入時の板 厚の比 $\left(B / t_{s}\right)$ で整理することにより特徴付けができる。

（2）艺りはリブ肩部付近の繊維配向の迁回によって生 じ，100\% チャージに比べ，60\%，30\% チャージで成形を 行うことによりそりを抑制できる。また，低チャージ率 におけるそりは，設計時に100\% チャージのような流動 をしないリブ形状を選択することによりそりは低減でき る。

(3) ヒートクラックはウエルドラインやレジンリッチ などの低強度部分と熱收縮による残留応力の集中部分が 
重なると発生する

(4) SMC の成形 CAD システムの構築には成形過程に 生じる繊維配向の把握が必要である。

(平成 8 年 3 月19日 日本材料学会第25回 FRP シンポジウムにて講演)

\section{参 考 文 献}

1）片山傳生, 足立睦夫, 早川雄三, 箱谷昌宏, 日本材料学 会第24回FRPシンポジゥム講演論文集, p.72（1995）.

2 ) Duck-ki Kim, Journal of Materials Proc.Tech., 49, p.333 (1995).

3 ) 平井恒夫, 片山傳生, 山部 昌, 石島 守, 日本材料学 会第19回FRPシンポジゥム講演論文集, p.149（1990）.

4 ) 平井恒夫, 片山傳生, 葛西則夫, 日本材料学会第 22 回FRP
シンポジウム講演論文集, p.104 (1993).

5) T. Hirai and T. Katayama, Proc. of ICCM-II, p.1283 (1978).

$6)$ M. Yamabe, T. Fujiwara, T. Hirai and T. Katayama, Proc. of 31st International SAMPE Symposium, p.1666 (1986).

7) T. Hirai, T. Katayama, M. Yamabe and K. Watanabe, Proc. of International Symposium on FRP/CM, p.1, 5-c (1988).

8 ) T. Hirai, T. Katayama, M. Yamabe and M. Ishijima, Proc. of ICCM/VIII, p.1, 10-N (1991).

9）船津和守, “高分子 · 複合材料の成形加工”, p.465（1992） 信山社

10) T. Hirai, T. Katayama and M. Shinohara, Proc. of 2nd Japan International SAMPE Symposium, p.705 (1991).

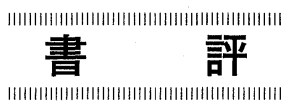

“材料の設計（先端材料シリーズ）”

日本材料科学会（編）

（1995 年，裳華房発行，B5 判，157 ページ，本体価格 3800 円）

本書は, 大きくセラミックスの材料設計（第 1 章），半導体設計（第 2 章）执よび設計支援システム（第 3 章）の 3 章 から構成されている.

第 1 章のセラミックスの材料設計はガラスとセラミックス（焼結体）に分かれ，ガラスの節では，ガラス材料の持つ 特徵について述べられ，現在使われている代表的な数值解析法が紹介されている，さらに，各種の特性を例にとって，ど のように設計していくのかについて具体的に説明され，その作製法についても触れられている．七ラミックスの節では， 固溶体を生成するスピネルやペロブスカイト型構造を有する複合酸化物を例にとって，その生成相や諸物性の予測につい て説明され，さらに，複合組織を有する場合の複合則についても解説されている．また，焼結体の微細構造や微粒子の 外形設計についても解説されている.

第 2 章の半導体設計では, 半導体の基礎である電子帯構造について説明され，さらに，これらの材料固有の電子帯構造 をモディフィケーションするための方法についても説明されていると共に，実際のデバイスにどのように材料を選択すれ ばよいのかを, 電子材料としてエレクトロントランジスタ（RHET）, 光材料としてアバランシェ・フォトダイオード (APD) を例に取り上げ，分かりやすく解説されている.

第 3 章の設計支援システムでは，生理活性物質を例にとって，その活性特性と構造との関係を解明する手順が説明され， この手順を効率よく実行するために，コンピュータによるデータベースを利用した解析が紹介されている．設計支援シス テムがさらに普及するためには, 表現と演繹能力を結合した知識処理を兼ね備えたデータベースの構築の重要性が指摘さ れ，実際に著者らの研究室で開発されたプログラム（KAUS）を例にとって知識处理システムの説明が行われている.

材料の研究，開発，設計の高度化に伴って，炎れらを支援するシステムにも高度の機能が要求されてきている. 本書 は, コンピュータを利用した材料設計だけでなく，実際の作製方法についても解説され，これから材料の設計に取り組も うとされている大学生, 研究者, エンジニアに推奨できる一冊である. 